\title{
Ethical issues surrounding the transplantation of organs from animals into humans
}

Citation for published version (APA):

Shaw, D., Dondorp, W., \& de Wert, G. (2018). Ethical issues surrounding the transplantation of organs from animals into humans. Revue Scientifique et Technique-office International des Epizooties, 37(1), 123-129. https://doi.org/10.20506/rst.37.1.2745

Document status and date:

Published: 01/04/2018

DOI:

10.20506/rst.37.1.2745

Document Version:

Publisher's PDF, also known as Version of record

Document license:

Taverne

Please check the document version of this publication:

- A submitted manuscript is the version of the article upon submission and before peer-review. There can be important differences between the submitted version and the official published version of record.

People interested in the research are advised to contact the author for the final version of the publication, or visit the DOI to the publisher's website.

- The final author version and the galley proof are versions of the publication after peer review.

- The final published version features the final layout of the paper including the volume, issue and page numbers.

Link to publication

\footnotetext{
General rights rights.

- You may freely distribute the URL identifying the publication in the public portal. please follow below link for the End User Agreement:

www.umlib.nl/taverne-license

Take down policy

If you believe that this document breaches copyright please contact us at:

repository@maastrichtuniversity.nl

providing details and we will investigate your claim.
}

Copyright and moral rights for the publications made accessible in the public portal are retained by the authors and/or other copyright owners and it is a condition of accessing publications that users recognise and abide by the legal requirements associated with these

- Users may download and print one copy of any publication from the public portal for the purpose of private study or research.

- You may not further distribute the material or use it for any profit-making activity or commercial gain

If the publication is distributed under the terms of Article $25 \mathrm{fa}$ of the Dutch Copyright Act, indicated by the "Taverne" license above, 


\title{
Ethical issues surrounding the transplantation of organs from animals into humans
}

\author{
D. Shaw ${ }^{(1,2) *}$, W. Dondorp ${ }^{(1)} \&$ G. de Wert ${ }^{(1)}$ \\ (1) Department of Health, Ethics and Society, Care and Public Health Research Institute, Maastricht University, \\ PO Box 616, 6200 MD Maastricht, The Netherlands \\ (2) Institute for Biomedical Ethics, University of Basel, Bernoullistrasse 28, 4056 Basel, Switzerland \\ ${ }^{*}$ Corresponding author: d.shaw@maastrichtuniversity.nl
}

\section{Summary}

In this paper, the authors provide an analysis of the ethical issues surrounding the transplantation of organs from animals into humans. The main objections to xenotransplantation relate to safety concerns for the recipient; public health concerns about new viruses spreading from animals to humans; the possibility of animals developing human features; concerns about human dignity; and the fact that animals must be sacrificed so humans can benefit from their organs. Despite these objections, the urgency of the organ shortage situation is such that xenotransplantation may be justified, if further advances make it a realistic possibility.

\section{Keywords}

Animal - Cell - Ethics - Genetic modification - Research - Stem cells Xenotransplantation.

\section{Introduction}

Despite the increasing number of people worldwide changing from eating meat to vegetarianism and veganism, billions of people eat non-human animals every day. In developed countries, eating meat is no longer necessary to achieve adequate nutritional intake, therefore meat consumption is harder to justify than it was in the past when maintaining a balanced diet was more challenging. But there is another potential use of animals that may be easier to justify: as sources of organs to transplant into humans.

The number of people who need a new organ is increasing every day. Most countries have highly developed organ donation and transplantation systems in place and stage frequent high-profile campaigns to promote organ donation from both living donors and deceased patients. Nevertheless, in spite of these Herculean efforts, and the consequent increase in donation rates, waiting lists for organs continue to grow because supply is still not adequate to meet demand. The result is that hundreds of patients die worldwide every day while waiting for an organ - and thousands more continue to suffer on dialysis while waiting for a kidney. In the United Kingdom alone, two or three people die every day waiting for an organ (1).

Several specific strategies have been suggested to increase donation rates and thus transplantation rates. The number of donations could be increased if fewer families refused to permit donations from their deceased relatives, but this issue is challenging due to the difficulty in discussing organ donation with bereaved or soon to be bereaved family members (2). Several countries have moved to so-called 'opt-out' systems, where consent for donation is presumed (or 'deemed') (3), but the issue of family refusal can actually be made worse by such legal changes (4). Several types of incentive have been suggested to increase donation rates. In the case of living donations, those in need of organs, and their families and friends, increasingly use social media to plead for an altruistic donation, but many are unsuccessful.

In order to help to meet the demand for organs, scientists and doctors have been trying for decades to transplant organs from animals into humans - or to perform xenotransplantation, to use the technical term. In this article, the authors explore the ethical issues raised by traditional xenotransplantation, the use of genetically 
modified animals for xenotransplantation, and the more recent possibility of so-called 'chimaera organs': human organs created from the intended recipient's stem cells and grown inside other animals (most probably pigs). Each of these types of xenotransplantation raises its own ethical issues, but each successive type has also solved some of the problems with the previous 'generation' of xenotransplantation. Broadly speaking, the main ethical issues concern the risk to recipients themselves, the risk to the public (public health concerns) and the harm done to animals by xenotransplantation. Some commentators have also voiced concerns relating to human dignity.

\section{Xenotransplantation}

The simplest form of xenotransplantation - though it is far from a simple procedure - is to remove organs from an animal and transplant them into a human. The term is defined as 'any procedure that involves the transplantation, implantation, or infusion into a human recipient of either live tissues or organs retrieved from animals, or, human body fluids, cells, tissue or organs that have undergone ex vivo contact with live non-human animal cells, tissues or organs' (5). Xenotransplantation was first attempted in the 1960s, and the most salient ethical issue quickly became apparent: organs from animals are even more likely to be rejected than those donated by humans. Because donor organs (whatever the source) are alien to the recipient's body, his or her immune system will almost always react negatively to the new organ(s) and attempt to reject it. Even patients who successfully undergo organ transplantation will have to keep taking immunosuppressant drugs for the rest of their lives. However, when the organ is taken ('donated' hardly seems appropriate) from an animal, immunosuppressants are unlikely to be effective because the organ is from a different species.

In the first attempts at xenotransplantation, it was quickly discovered that organs from animals are very swiftly rejected when transplanted into a human. Kidneys from chimpanzees were transplanted into six patients in the United States of America in 1964 - this species was chosen because of its close genetic relationship to humans, but the organs were rejected and all but one patient died within days (though the latter survived for nine months). In the same year, baboon kidneys were transplanted into six patients, none of whom survived longer than two months. In three other cases (a baboon heart and two baboon livers) in the 1980s and 1990s, the recipients all died within 100 days of transplantation. In terms of transplantation from other types of animal, one patient received a sheep heart in 1968 and died immediately, and one received a pig heart in 1992 and died within a day (6). These grim statistics led to the first efforts to genetically modify animals to decrease the chances of rejection (see next section).

Xenotransplantation of solid organs would only ever be considered for patients who 'super-urgently' needed an organ, because the risk of death involved in receiving a transplant would be too high for those who can afford to wait longer in the hope of receiving an organ from a human donor. Of course, if the alternative to trying xenotransplantation is death from organ failure, the very slim chance of successful transplantation without rejection is likely to appeal to patients. However, even for this small group of patients, there is another reason why xenotransplantation might be problematic, as discussed below.

The other major ethical issue affecting xenotransplantation concerns the potential consequences if the organ is not rejected: the transplant could result in the transmission of an existing animal virus to its human host, or (worse) interaction between the animal organ and its human host could create a new virus that could then cause a pandemic of infection. This risk of 'zoonosis' makes xenotransplantation an issue not only of individual consent and risk, but also of public health ethics. This means that the consequences of xenotransplantation not only affect the recipient (and the animal from which the organ is taken) but also the wider public. As Sheila McLean and Laura Williamson describe: 'The risks of infectious disease potentially associated with xenotransplantation mean that the decision of one patient could compromise the health of third parties: their close contacts, healthcare providers or others' (7). Because of these concerns, monitoring for infectious disease following xenotransplantation might not only apply to the recipient of the organ, but also to anyone in frequent contact with him or her in order to prevent any small but potentially catastrophic risk of a pandemic from being realised. This in turn raises some ethical issues regarding the possibly coercive nature of any such monitoring; a person might want to receive a xenotransplant, but consent should also be sought from his or her family members if they must submit to long-term monitoring for any zoonosis. Any patient who was not willing to consent to such monitoring would have to be excluded from any xenotransplantation research, and the same would apply if their family members and any other close intimates were not also willing to be monitored.

Finally, some conservative commentators objected to the original attempts at xenotransplantation because they regarded it as contrary to human dignity to insert parts of animals into human bodies, even to preserve life. This is because many religious views hold that human kind is a special type of animal (or not an animal at all) and this distinction should not be blurred by cross-species mixing of any sort. This view is illustrated well by the 
official Catholic Church statement on xenotransplantation: 'From our point of view, supported by the biblical perspective that asserts, as stated above, that man is created "in the image and likeness of God" (cf. Gen 1: 26-27), we reaffirm that humans have a unique and higher dignity' (8). However, even the Catholic Church now acknowledges that xenotransplantation is ethically permissible (8), though it has some concerns about more recent developments in the field (see below).

Despite the relative lack of success during the initial attempts at xenotransplantation, it is important to bear in mind that solid organs are not the only parts of animals that can be transplanted into humans. Despite the fact that the xenotransplantation of solid organs has not been successful, other parts of animals have been transplanted with some success. Many patients suffering from heart disease have had pig heart valves transplanted into their chests, with high success rates. Pigskin has also been used successfully in burns victims without any evidence of zoonosis occurring.

\section{Transgenic animals and chimaera organs}

Given the failure of traditional xenotransplantation to provide viable organs, the focus has shifted over the last few decades towards genetically modifying animals and the organs obtained from them that are less likely to be rejected following transplantation. Although the use of genetically modified (GM) animals for organ production does appear promising in terms of reducing rejection rates, it raises one other ethical issue not encountered by traditional xenotransplantation: by definition, it involves GM, which some object to on moral grounds. The aforementioned human dignity argument resurfaced when transgenic animals were suggested as a source of organs. It is perhaps unsurprising that people who objected to the mere transplantation of an animal organ into a human would also object to the addition of human genes to an animal. However, these concerns do not have a sound foundation. As the Academy of Medical Sciences put it:

'It has long been accepted that the dignity of man does not rule out many ways in which animal and human materials are combined. After all, most humans eat meat or drink milk. Of course, some people are vegans on moral grounds, but these grounds are not that the very idea of combining human and animal materials is wrong, but that it is wrong to kill animals for human consumption, that dairy farming is exploitative and so on. Again, humans are not demeaned by the incorporation of parts of non-human animals (such as heart valves from pigs) through xenotransplantation, though it is possible to object to this practice on other grounds. Similarly, therefore, the creation by another form of xenotransplantation of animals, which include significant human elements, cannot be held to threaten human dignity just because it humanises the animals involved' (9).

Using genetically modified animals for xenotransplantation remains a promising potential future source of organs, particularly given recent advances such as CRISPR/Cas9 (Clustered Regularly Interspaced Short Palindromic Repeats-associated protein-9 nuclease), a gene-editing technique that greatly increases scientists' ability to alter genetic code accurately and that may reduce the risk of zoonosis further still (10). However, transgenic animals are still not at the stage where clinical trials are a possibility. In recent years, therefore, the focus has moved on to another, newer biotechnology: the creation of human organs inside animals for transplantation purposes, or so-called chimaera organs. To some people, transplanting animal organs into humans already seems like science fiction, and tinkering with the genetic code of animals in order to facilitate this endeavour even more so. Chimaera organs add induced pluripotent stem cells (iPSCs) to the mix.

Although the technique has not yet been attempted in humans, scientists have successfully taken stem cells from one species (a mouse) and, by modifying these cells and injecting them into the embryo of another mutant species (a rat), have succeeded in growing a mouse pancreas inside a rat. Without these mouse cells, the genetically modified rat would have been born without a pancreas. What is the relevance of this experiment for humans? In the near future, a patient who needs a new kidney could provide a few skin cells to scientists who would then induce these cells back into their pluripotent state, in which they can become several different types of cell. The cells would then be inserted into a modified embryo of a suitable species (probably a pig; possibly a non-human primate), and that embryo would then develop and gestate normally - except for the fact that its kidneys would be almost entirely human, both genetically and in terms of tissue. Once the piglet had been born and had grown sufficiently, the kidney(s) could be removed and transplanted into the intended recipient. It might appear that this is not xenotrans plantation because the organ itself is human. However, the term xenotransplantation refers to the source, rather than the nature, of an organ. This means that chimaera organs are a new type of xenotransplantation.

The main advantage offered by chimaera organs is that they would entirely avoid the issue of rejection faced by other forms of xenotransplantation because the organ would be human, not animal (11). Indeed, it would not only be human, but also composed of the recipient's own DNA - meaning that recipients of chimaera organs would probably not even have to take any immuno 
suppressant drugs. It seems counter-intuitive that organs grown inside an animal would be less likely to be rejected than those donated from a human, but that is the unusual nature of chimaera organs.

Zoonosis should also be minimised by using chimaera organs. Owing to the fact that the organ being transplanted is human, not porcine (or some other species), the already low risk of zoonosis will be reduced even further. However, it is important to bear in mind that, even if the risk of zoonosis is almost zero, safety assessment focuses not only on the magnitude of the risk, but also the magnitude of the consequences if that risk is realised. In other words, it might be true that the zoonosis is extremely unlikely to ever occur, but that millions of people could die in a pandemic if it did occur. To guard against any such consequences, patients receiving chimaera organs would be extremely closely monitored to avoid any public health emergencies. However, while it might address these issues, such monitoring can raise new questions about privacy (see above). As mentioned above, the use of CRISPR/Cas9 gene editing may reduce the risk of zoonosis further still (12).

Another ethical issue common to transgenic animals and chimaera organs is the theoretical possibility that introducing human DNA into an animal embryo could lead to the creation of an actual chimaera organism - such as a pig with physical or mental human features, or with human gametes. This is a very remote possibility, as genes for these particular traits can be 'knocked out' using existing genetic technologies. Creating chimaera organs may run a slightly higher risk of these unintended effects than that involved in creating transgenic animals because human stem cells are being inserted into an animal embryo, but the risk remains low - and even if it were realised, the consequences would not be serious. For example, 'even if human neurons were present in a pig brain, it is likely that they would act like pig neurons, being influenced by their environment rather than their genomic makeup' (11). Finally, in view of the possibility of chimaeras having human gametes, any concerns about human or hybrid embryos developing in animal wombs can be avoided by preventing those animals from mating.

An additional, related objection often raised in relation to chimaera organs is yet another version of the claim that mixing human and animal DNA is contrary to human dignity (13). Specifically, some religious commentators have argued against the creation of chimaeras that 'species integrity is ultimately defined by God, rather than by physical features. The fusion of human and nonhuman genomes may therefore be perceived as running counter to the sacredness of human life and humanity created in the image of God' (14). To some people of faith, such arguments may have some appeal, but to non-believers, they tend to seem unconvincing. The creation of chimaera organs for transplantation raises no new threats to human dignity that are not also present for transgenic animals. Indeed, many humans would argue that it displays a lack of dignity to claim a special dignity for humans - especially when humans treat other animals with such a lack of dignity. This finally leads to the ethical issue common to all types of xenotransplantation: the cost to animals.

\section{Exploiting animals for xenotransplantation}

Finally, as mentioned in the introduction, there is one ethical issue intrinsic to all three forms of xenotransplantation discussed in this article: the fact that using non-human animals to produce organs for humans harms those animals. Any research into xenotransplantation must involve by definition the use and normally the destruction of animals (because animal welfare legislation requires the euthanasia of all animals used in experiments, even those that could potentially survive - to avoid distress). Animal research is governed by the 'Three Rs': replacing, reducing and refining the use of animals in research (15). The Three Rs themselves are subject to two criteria: proportionality and subsidiarity. The former of these means that the use of animals must be justified by any prospective benefit, and the latter means that this benefit cannot be attained in some other, less ethically problematic way. The use of animals in xenotransplantation research could probably be justified because xenotransplantation will save lives if it reaches the clinic - and for comparison, animals are sacrificed for research that is much less likely to save lives. It should be noted that it is not just the animals from which organs are taken that are sacrificed in xenotransplantation research - before organs can be transplanted into humans, other animals must be the test recipients, and most transgenic pig transplant work involves transplantation into primates (10).

However, if any type of xenotransplantation was perfected and began to be used routinely in humans, this might be regarded as more ethically problematic because it would involve the systematisation of creating and killing nonhuman animals in order to save human lives. In addition, it is important to note that any such development would represent a new type of use for animals - not for meat consumption, research or clothing, but as a source of organs for humans. Although the Three Rs are intended to govern research, whether the use of animals for this purpose would meet the criteria of proportionality and subsidiarity can still be considered.

In the context of a world where animals are unnecessarily killed in their millions every day for human consumption, 
using pigs as a source of lifesaving organs is comparatively easy to justify in terms of proportionality. With regard to subsidiarity, using pigs as an organ source is also justifiable, because, despite the fact that some organs are available from humans, there are not sufficient numbers of them to meet the demand. But what if it transpired that pigs were not a suitable model, and that primates had to be used instead? Primates are still sometimes used for research, but the rationale for this use is that they are the most suitable candidates for promising therapies for use in humans, and a condition of their use is that they will be used only in limited numbers. The first of these points would also apply in the case of chimaera organs, as the organ will save a life, but the second point would not, as 'industrialising' the use of primates for the production of organs would increase the number of primates being sacrificed. Nonetheless, given the prospective benefits to humans, this increased sacrifice might be deemed proportional - for lesser primates, though perhaps not for great apes, which are now treated as persons in some countries. (Even if greater moral value is accorded to primates than to pigs, substantially greater value is still accorded to humans.) If the subsidiarity criterion is met for pigs, it can also be assumed that it is met for primates, as here the question is not whether the benefit justifies using them for this purpose, but whether there is any alternative source of organs. As the authors have suggested elsewhere, 'another interesting issue concerning subsidiarity arises from the possibility that creating organs inside pigs might be workable but less effective than using primates' (16). If this were the case, it would probably not be possible to meet the subsidiarity criterion for using primates, as pigs would provide another, more ethically acceptable, source.

Finally, this paper should also consider the ethics of using animals to produce organs in a more objective sense. A thought experiment is useful here: consider the introduction of widespread xenotransplantation in a world where everyone is vegetarian or vegan. In such a society, where animals are not instrumentalised in the same way as they are in most countries today, it seems unlikely that xenotransplantation of any type - even the 'best' solution possibly offered by chimaera organs - would meet with public endorsement. This in turn suggests that the seeming permissibility of chimaera organs (and other types of transplantation) is largely due to status quo bias. Furthermore, even if xenotransplantation is considered to be morally acceptable under certain conditions, humans still have a responsibility to try to find other solutions for the scarcity of organs for transplantation, such as in vitro culture of tissue and organs, artificial organs, and organ printing (11). If such techniques are successfully developed, it is likely that neither the proportionality nor the subsidiarity conditions for xenotransplantation would be met.

\section{Conclusions}

Xenotransplantation is a promising biotherapy that has not yet borne fruit (17). Given that there are no strong ethical arguments against using the technology (based on current attitudes to animals and the absence of any viable alternative sources in addition to human donors), it is possible that clinical trials of xenotransplantation using transgenic animals or chimaera organs will take place in the next decade. If these trials are successful, hundreds of thousands of people could benefit from receiving new organs. However, if they do, it will come at a considerable cost; for each person who benefits, at least one animal must die. 


\title{
Questions éthiques suscitées par la transplantation chez l'homme d'organes provenant d'animaux
}

\author{
D. Shaw, W. Dondorp \& G. de Wert
}

\section{Résumé}

Les auteurs analysent les questions éthiques suscitées par la transplantation chez l'homme d'organes provenant d'animaux. Les principales objections contre la xénotransplantation se réfèrent aux risques pour la santé du receveur, aux problèmes de santé publique liés à une éventuelle propagation chez l'homme de virus émergents d'origine animale, au risque que des animaux acquièrent des caractéristiques humaines, au respect de la dignité humaine et à la nécessité de sacrifier des animaux pour que des êtres humains puissent bénéficier de leurs organes. Malgré ces objections, le déficit d'organes est tel que la xénotransplantation pourrait se justifier à condition que les avancées scientifiques en garantissent la faisabilité à l'avenir.

\section{Mots-clés}

Animal - Cellule - Cellule souche - Éthique - Modifications génétiques - Recherche Xénotransplantation.

\section{Cuestiones éticas en torno al trasplante de órganos animales al ser humano}

\author{
D. Shaw, W. Dondorp \& G. de Wert
}

\section{Resumen}

Los autores proponen un análisis de las cuestiones éticas que rodean el trasplante de órganos animales al ser humano. Las principales objeciones que suscita el xenotrasplante tienen que ver con: la preocupación por la seguridad del receptor; la problemática de salud pública ligada a la eventual propagación de nuevos virus que pasen de los animales al ser humano; la posibilidad de que los animales adquieran atributos humanos; consideraciones vinculadas a la dignidad humana; $y$ el hecho de que haya que sacrificar a animales para que los humanos se beneficien de sus órganos. Pese a todas estas objeciones, la urgencia de la situación de penuria de órganos es de tal magnitud que los xenotrasplantes podrían estar justificados si se sigue progresando lo bastante como para hacer de ellos una perspectiva realista.

\section{Palabras clave}

Animal - Célula - Célula madre - Ética - Investigación - Modificación genética Xenotrasplante. 


\section{References}

1. Anon. (2016). - NHS Blood and Transplant potential donor audit. Summary report for the 12 month period. National Health Service (NHS), Watford, $11 \mathrm{pp}$. Available at: https://nhsbtdbe.blob.core.windows.net/ umbraco-assets-corp/3184/pda_report_1516.pdf (accessed on 4 December 2017).

2. Shaw D., Georgieva D., Haase B., Gardiner D., Lewis P., Jansen N., Wind T., Samuel U., McDonald M. \& Ploeg R.; ELPAT Working Group on Deceased Donation (2017). Family over rules? An ethical analysis of allowing families to overrule donation intentions. Transplantation, 101 (3), 482487. doi:10.1097/TP.0000000000001536.

3. Welsh Government (2017). - Organ Donation Wales. Organ donation has changed. Can I opt out? Available at: http:// organdonationwales.org/Organ-Donation-is-changing-inWales/Can-I-opt-out-yet/?lang=en (accessed on 20 December 2017).

4. Shaw D. (2017). - Presumed consent to organ donation and the family overrule. J. Intensive Care Soc., 18 (2), 96-97. doi:10.1177/1751143717694916.

5. United Kingdom Department of Health (2006). Xenotransplantation guidance. Department of Health, London, 1-7. Available at: http://webarchive.nationalarchives. gov.uk/20090503114534/http://www.dh.gov.uk/en/ Publicationsandstatistics/Publications/PublicationsPolicy AndGuidance/DH_063075 (accessed on 20 December 2017).

6. Nuffield Council on Bioethics (1996). - Animal-to-human transplants: the ethics of xenotransplantation. Nuffield Council on Bioethics, London, 168 pp. Available at: http://nuffieldbio ethics.org/wp-content/uploads/xenotransplantation.pdf (accessed on 4 December 2017).

7. McLean S. \& Williamson L. (2007). - The demise of UKXIRA and the regulation of solid-organ xenotransplantation in the UK. J. Med. Ethics, 33 (7), 373-375. doi:10.1136/jme.2007.020768.

8. Pontifical Academy for Life (2001). - Prospects for xenotransplantation: scientific aspects and ethical considerations. Pontifical Academy for Life, Vatican City. Available at: www.vatican.va/roman_curia/pontifical_ academies/acdlife/documents/rc_pa_acdlife_doc_20010926_ xenotrapianti_en.html (accessed on 4 December 2017).
9. Academy of Medical Sciences (2011). - Animals containing human material. Academy of Medical Sciences, London, 148 pp. Available at: https://acmedsci.ac.uk/policy/policyprojects/animals-containing-human-material (accessed on 20 December 2017).

10. Reardon S. (2015). - New life for pig organs. Gene-editing technologies have breathed life into the languishing field of xenotransplantation. Nature, 527 (7577), 152-154. Availableat: www.nature.com/polopoly_fs/1.18768!/menu/main/ topColumns/topLeftColumn/pdf/527152a.pdf?origin=ppub (accessed on 4 December 2017).

11. Shaw D., Dondorp W., Geijsen N. \& de Wert G. (2015). Creating human organs in chimaera pigs: an ethical source of immunocompatible organs? J. Med. Ethics, 41 (12), 970-974. doi:10.1136/medethics-2014-102224.

12. Yang L., Guell M., Niu D., George H., Lesha E., Grishin D., Aach J., Shrock E., Xu W., Poci J., Cortazio R., Wilkinson R.A., Fishman J.A. \& Church G. (2015). - Genome-wide inactivation of porcine endogenous retroviruses (PERVs). Science, 350 (6264), 1101-1104. doi:10.1126/science.aad1191.

13. MacKellar C. (2007). - Chimeras are a shocking affront to human dignity. Catholic Herald, 14 September.

14. MacKellar C. (2007). - File 34: Chimeras, hybrids and 'cybrids'. Christian Medical Fellowship (CMF), 3 pp. Available at: http://admin.cmf.org.uk/pdf/cmffiles/34_hybrids. pdf (accessed on 4 December 2017).

15. National Centre for the Replacement, Refinement and Reduction of Animals in Research (NC3Rs) (2013). The 3Rs: what are the 3Rs? Available at: www.nc3rs.org.uk/ the-3rs (accessed on 4 December 2017).

16. Shaw D., Dondorp W. \& de Wert G. (2014). - Using nonhuman primates to benefit humans: research and organ transplantation. Med. Hlth Care Philos., 17 (4), 573-578. doi:10.1007/s11019-014-9565-x.

17. Wu J., Greely H.T., Jaenisch R., Nakauchi H., Rossant J. \& Belmonte J.C. (2016). - Stem cells and interspecies chimaeras. Nature, 540 (7631), 51-59. doi:10.1038/nature20573. 
